\title{
Comparative effectiveness of renin-angiotensin system blockers and other antihypertensive drugs in patients with diabetes: systematic review and bayesian network meta-analysis
}

\begin{abstract}
Objective To assess the effects of different classes of antihypertensive treatments, including monotherapy and combination therapy, on survival and major renal outcomes in patients with diabetes.

Design Systematic review and bayesian network meta-analysis of randomised clinical trials.

Data sources Electronic literature search of PubMed, Medline, Scopus, and the Cochrane Library for studies published up to December 2011.

Study selection Randomised clinical trials of antihypertensive therapy (angiotensin converting enzyme (ACE) inhibitors, angiotensin receptor blockers (ARBs), a blockers, $\beta$ blockers, calcium channel blockers, diuretics, and their combinations) in patients with diabetes with a follow-up of at least 12 months, reporting all cause mortality, requirement for dialysis, or doubling of serum creatinine levels.

Data extraction Bayesian network meta-analysis combined direct and indirect evidence to estimate the relative effects between treatments as well as the probabilities of ranking for treatments based on their protective effects.

Results 63 trials with 36917 participants were identified, including 2400 deaths, 766 patients who required dialysis, and 1099 patients whose serum creatinine level had doubled. Compared with placebo, only ACE inhibitors significantly reduced the doubling of serum creatinine levels (odds ratio $0.58,95 \%$ credible interval 0.32 to 0.90 ), and only $\beta$ blockers showed a significant difference in mortality (odds ratio $7.13,95 \%$ credible interval 1.37 to 41.39 ). Comparisons among all treatments showed no statistical significance in the outcome of dialysis. Although the beneficial
\end{abstract}

effects of ACE inhibitors compared with ARBs did not reach statistical significance, ACE inhibitors consistently showed higher probabilities of being in the superior ranking positions among all three outcomes. Although the protective effect of an ACE inhibitor plus calcium channel blocker compared with placebo was not statistically significant, the treatment ranking identified this combination therapy to have the greatest probability $(73.9 \%)$ for being the best treatment on reducing mortality, followed by ACE inhibitor plus diuretic (12.5\%), ACE inhibitors (2.0\%), calcium channel blockers (1.2\%), and ARBs $(0.4 \%)$.

Conclusions Our analyses show the renoprotective effects and superiority of using ACE inhibitors in patients with diabetes, and available evidence is not able to show a better effect for ARBs compared with ACE inhibitors. Considering the cost of drugs, our findings support the use of ACE inhibitors as the first line antihypertensive agent in patients with diabetes. Calcium channel blockers might be the preferred treatment in combination with ACE inhibitors if adequate blood pressure control cannot be achieved by ACE inhibitors alone.

\section{Introduction}

Diabetes is a global epidemic and a major cause of death and end stage renal disease. ${ }^{12}$ Angiotensin converting enzyme (ACE) inhibitors and angiotensin receptor blockers (ARBs) are the two major classes of drugs among blockers of the renin-angiotensin system and are believed to have similar and interchangeable renoprotective effects than other classes of antihypertensive agents..$^{3-5}$ Therefore all major guidelines in the relevant specialty suggest the use of either ACE inhibitors or ARBs as the first 
line treatment in hypertensive patients with diabetes when cost is not a concern. ${ }^{126-10}$ However, clinical trials designed to compare an ACE inhibitor directly with an ARB are rare, and the difference in protective effects between ACE inhibitors and ARBs for patients with diabetes remains inconclusive.

Additionally, many hypertensive patients with diabetes require other antihypertensive treatments in combination with renin-angiotensin system blockers to achieve appropriate control of blood pressure, but until now there has been no consensus about the choice of treatments for combination therapy.

Bayesian network meta-analysis combines both direct and indirect evidence for multiple treatments comparisons to estimate the interrelations across all treatments; and its usefulness has been shown in many previous studies on various medical conditions and interventions. ${ }^{11-16}$ This approach allows a unified and coherent analysis of data from randomised clinical trials for comparisons of multiple treatments, without breaking randomisation of treatments within each trial. ${ }^{15}{ }^{17}$ In this systematic review and network meta-analysis, we evaluated the effects of different classes of renin-angiotensin system blockers and other antihypertensive treatments, including monotherapy and combination therapy, on survival and major renal outcomes in patients with diabetes.

\section{Methods}

\section{Data sources and searches}

We searched four electronic databases (Medline, PubMed, Scopus, and the Cochrane Library) between 1970 and 15 December 2011 for randomised clinical trials investigating any antihypertensive drug treatment for patients with diabetes, with Medical Subject Headings (MeSH) and text words. We searched additional studies in the reference lists of all identified publications, including relevant meta-analyses and systematic reviews. The supplementary file provides a detailed study protocol and description of the search strategies.

\section{Study selection}

We included randomised, parallel group design clinical trials comparing the effects of any single or combination of antihypertensive drugs with placebo or other classes of active treatments in patients with diabetes older than 18 years, with a follow-up of at least 12 months. Included studies had to report at least one of three outcomes: incidence of all cause death, end stage renal disease, or doubling of serum creatinine levels. End stage renal disease was defined as the need for dialysis therapy or kidney transplantation. We included studies in patients with any type of diabetes and any level of albuminuria. Eligible studies had to be published as full length articles or letters in peer reviewed journals. There was no restriction on language of publication.

\section{Data extraction and quality assessment}

Two investigators (H-YW, J-WH) independently extracted the following information and entered it into a database: study design, patients' characteristics, interventions, comparisons, and outcomes (all cause mortality, end stage renal disease, and doubling of serum creatinine level). When relevant information on design or outcomes was unclear, or when doubt existed about duplicate publications, we contacted the original authors for clarifications. Two investigators $(\mathrm{H}-\mathrm{YW}, \mathrm{J}-\mathrm{WH})$ independently evaluated the methodological quality of eligible trials by using the Cochrane Collaboration's tool for assessing risk of bias (random sequence generation, allocation concealment, blinding of participants and personnel, blinding of outcome assessment, incomplete outcome data, selective reporting, and other sources of bias). ${ }^{18}$ Disagreements between the two authors were resolved by discussion. When the disagreement persisted, two other senior investigators (K-YH, K-DW) were consulted to attain consensus.

\section{Data synthesis and analysis}

All data from each eligible study were extracted and entered into a standardised spreadsheet (Microsoft Excel 2007; Microsoft, Redmond, WA). We analysed three treatment outcomes separately (all cause mortality, end stage renal disease, and doubling of serum creatinine level). Firstly we performed traditional pairwise meta-analyses for studies that directly compared different treatment arms. Then we performed bayesian network meta-analyses to compare different antihypertensive drug based therapies (ACE inhibitors, ARBs, $\beta$ blockers, calcium channel blockers, diuretics, combinations of ACE inhibitor plus calcium channel blocker, ACE inhibitor plus diuretic, ARB plus calcium channel blocker, ARB plus diuretic, and ACE inhibitor plus ARB, as well as placebo, to each other.

We performed traditional pairwise meta-analysis by using Stata software (version 10.0, StataCorp, College Station, TX). Using the method of DerSimonian and Laird random effects model we calculated the pooled estimates of odds ratios and $95 \%$ confidence intervals of direct comparisons between two strategies. ${ }^{18}$ Heterogeneity of treatment effects across studies was assessed by $\mathrm{I}^{2}$ and the Cochrane Q test. ${ }^{18}$ Publication bias was examined with the funnel plot method, the Begg's adjusted rank correlation test, and the Egger's regression asymmetry test. ${ }^{19} 20$

We performed network meta-analysis using the bayesian hierarchical random effects model proposed by Lu and Ades. ${ }^{12}$ The advantages of using a bayesian meta-analytical approach are that direct probability statements on treatment comparisons can be made, and that all evidence for a specific problem can be taken into account as it includes evidence on both indirect and direct comparisons, and as such allows estimation of the comparisons between interventions that have not been examined directly in previous trials. ${ }^{14}$ We used software package WinBUGS (version 1.4.3, MRC Biostatistics Unit, Cambridge, UK) to perform network meta-analysis, with random effects models for multiarm trials developed by Ades and colleagues (Multi-Parameter Evidence Synthesis Research Group, University of Bristol, UK; downloaded 30 November 2011 from www.bris.ac.uk/cobm/research/mpes/mtc.html). The pooled estimates were obtained using the Markov Chains Monte Carlo method. In our bayesian analysis, we used non-informative priors with vague normal (mean 0 , variance 10000 ) and uniform $(0-2)$ prior distributions for parameters such as means and standard deviations, respectively. ${ }^{12} \mathrm{We}$ examined the impact of different choices of prior distribution in sensitivity analyses. For each model, we generated 100000 simulations for each of the two sets of different initial values, and we discarded the first 50000 simulations as the burn-in period. The achievement of convergence was assessed using the Brooks-Gelman-Rubin statistic. ${ }^{21}$ The median of the posterior distribution based on 100 000 simulations was reported as the point estimate, and we obtained the corresponding $95 \%$ credible intervals using the 2.5th and 97.5th percentiles of the posterior distribution, which could be interpreted in a way similar to conventional $95 \%$ confidence intervals. ${ }^{15}$ When a loop connected three treatments, it was possible to evaluate the inconsistency between direct and indirect evidence. ${ }^{13}{ }^{16} \mathrm{We}$ used the node splitting method to calculate the inconsistency of the model, which separated 
evidence on a particular comparison into direct and indirect evidence. ${ }^{22}{ }^{23}$ We then evaluated the agreement between the direct and indirect evidence and reported its bayesian $P$ value. ${ }^{23}$ We carried out sensitivity analyses by the same methods, after omission of data from specific studies (studies with few patient numbers and events in a specific treatment arm, and studies with a large population that may dominate the data of specific treatment arms).

The treatments were ranked for each outcome in each simulation on the basis of their posterior probabilities. We assessed the probability that each treatment was the most effective therapy, the second best, and so on, by counting the proportion of simulations in which each treatment had the smallest odds ratio, the second smallest, and so on. Even if the differences in effect size among treatments may be small, clinical decisions about the choice of treatments can still be suggested based on the probabilities of treatment ranking. ${ }^{164-26}$ All results are reported as odds ratios with corresponding $95 \%$ credible intervals, as well as the probabilities of ranking by treatment.

\section{Results}

We found 691 articles from a search of Medline, 1451 from PubMed, 95 from Scopus, 1873 from the Cochrane Library, and one additional article from hand searching (fig $1 \Downarrow$ ). After results from these searches were combined and duplicates removed, the total number of articles was 2150 . Of these, 1642 were excluded on the basis of their title and abstract. Of the 508 that underwent full text evaluation, 67 met our inclusion criteria.

\section{Study characteristics}

We found 63 eligible studies from 67 articles, which enrolled a total of 36917 patients and evaluated 11 different antihypertensive treatment regimens, including placebo. Death from any cause was reported in 2400 of 36810 patients from 62 studies. End stage renal disease occurred in 766 of 25813 patients from 19 studies. Doubling of serum creatinine levels was noted in 1099 participants from 13 studies providing data on 25055 patients. Table $1 \Downarrow$, supplementary tables A and B, and supplementary figures A and B summarise the clinical and methodological characteristics as well as the main outcomes of each trial. Figure $2 \Downarrow$ shows the network for the comparison of treatment regimens, as well as the results of direct comparisons. No heterogeneity or publication bias was identified among those pairwise comparisons of different treatment regimens (see supplementary table A). Quality assessment showed that inadequate random sequence generation and allocation concealment, as well as lack of blinding of participants and personnel, were the main causes of potential bias (see supplementary table B and supplementary figures A and B).

\section{Effects of antihypertensive treatments on all cause mortality}

A total of 5176 patients $(14.1 \%)$ were specifically assigned to ACE inhibitor therapy, $7162(19.5 \%)$ to ARB therapy, $71(0.2 \%)$ to $\beta$ blocker therapy, 1729 (4.7\%) to calcium channel blocker therapy, and $319(0.9 \%)$ to diuretic therapy. Overall, 640 patients $(1.7 \%)$ were assigned to the combination therapy of ACE inhibitor plus calcium channel blocker, $5762(15.7 \%)$ to ACE inhibitor plus diuretic therapy, $46(0.1 \%)$ to ARB plus calcium channel blocker therapy, $56(0.2 \%)$ to ARB plus diuretic therapy, $26(0.1 \%)$ to ACE inhibitor plus ARB therapy, and 15823 patients $(43.0 \%)$ received placebo.
Table $2 \Downarrow$ and supplementary table $\mathrm{C}$ show the pooled estimates for the results of network meta-analysis on all cause mortality. Figure $3 \Downarrow$ shows the distribution of probabilities for each treatment being ranked at different positions for the outcome of all cause mortality. Compared with placebo, only $\beta$ blockers showed a significant difference in all cause mortality (odds ratio $7.13,95 \%$ credible interval 1.37 to 41.39 ). Compared with $\beta$ blockers, the combination treatment of ACE inhibitor plus calcium channel blocker $(0.067,0.008$ to 0.559$)$ yielded the most significant effect on reducing mortality, followed by ACE inhibitor plus diuretic $(0.121,0.020$ to 0.658$)$, ACE inhibitors $(0.137,0.023$ to 0.711$)$, placebo $(0.140,0.024$ to 0.732$)$, calcium channel blockers $(0.145,0.025$ to 0.728$)$, and ARBs (0.153, 0.025 to 0.793 ). Except for $\beta$ blockers, the differences between treatments, such as ACE inhibitors versus ARBs, were not significant. Although the protective effect of ACE inhibitor plus calcium channel blocker compared with placebo was not statistically significant $(0.51,0.15$ to 1.35$)$, ACE inhibitor plus calcium channel blocker had the greatest probability (73.9\%) for being the best treatment option on reducing mortality. The treatment of ACE inhibitor plus diuretic (46.0\%) and ACE inhibitors $(24.5 \%)$ showed the highest probability for being in the second and third ranking positions, respectively; whereas ARBs showed the highest probability (35.3\%) of being ranked at the sixth position. $\beta$ blockers showed the worst ranking compared with other treatments $(69.4 \%$ probability of being in the last position). Extremely wide credible intervals were noted for the treatments of ARB plus calcium channel blocker, ARB plus diuretic, and ACE inhibitor plus ARB, indicating great uncertainty in the estimation of treatment effect owing to small patient numbers and rare death events among those treatment arms. Sensitivity analyses showed robust results (see supplementary table E) since the rank ordering and statistical significance remained the same after omitting studies comparing with either ARB plus calcium channel blocker, ${ }^{27} \mathrm{ARB}$ plus diuretic, ${ }^{28}$ or ACE inhibitor plus ARB.$^{29}$ The combination therapy of ACE inhibitor plus calcium channel blocker showed the highest probability of being at the best ranking position, whereas the sensitivity analysis showed that omitting such a treatment arm did not impact on the ranking order and statistical significance of the remaining treatments (see supplementary table E). The DIABHYCAR trial ${ }^{30}$ and the ROADMAP trial $^{31}$ (see panel for full trial names) were the largest eligible studies evaluating all cause mortality and renal outcomes of ACE inhibitor therapy and ARB therapy, respectively. The sensitivity analysis showed that omitting either trial made little difference to the estimated treatment effects and the rank ordering of treatments (see supplementary table E). The data for treatment of ACE inhibitor plus diuretic in our analysis is mostly provided from the ADVANCE trial, which showed that such treatment reduced the risk of mortality. ${ }^{32}$ The sensitivity analysis showed that omitting either the ADVANCE trial or the treatment arm of ACE inhibitor plus diuretic made little difference to the estimated treatment effects and the rank ordering except for the ACE inhibitor plus diuretic therapy arm (see supplementary table E).

\section{Effects of antihypertensive treatments on end stage renal disease}

A total of 3165 patients (12.3\%) were specifically assigned to ACE inhibitor therapy, $4167(16.1 \%)$ to ARB therapy, 40 (0.2\%) to $\beta$ blocker therapy, 647 (2.5\%) to calcium channel blocker therapy, and 5569 (21.6\%) to the combination therapy of ACE inhibitor plus diuretic. In addition, 12225 patients (47.4\%) were randomised to receive placebo. 
Table 2 and supplementary table $\mathrm{C}$ show the pooled estimates for the outcome of end stage renal disease in network meta-analysis. Figure 3 shows the distribution of probabilities for each treatment being ranked at different positions for the outcome of end stage renal disease. All comparisons among treatments showed no statistical significance in the outcome of end stage renal disease. For reducing the incidence of end stage renal disease, ACE inhibitors showed a higher probability of being at the top two ranking positions $(29.6 \%, 37.5 \%$, respectively), closely followed by ARBs $(26.6 \%, 35.0 \%$, respectively). The combination therapy of ACE inhibitor plus diuretic was the treatment with the highest probability $(41.9 \%)$ of being in the last ranking position.

\section{Effects of antihypertensive treatments on doubling of serum creatinine levels}

A total of 2819 patients $(11.3 \%)$ were specifically assigned to ACE inhibitor therapy, 3951 (15.8\%) to ARB therapy, $16(0.1 \%)$ to $\beta$ blocker therapy, 585 (2.3\%) to calcium channel blocker therapy, and 5569 (22.2\%) to the combination therapy of ACE inhibitor plus diuretic. In addition, 12115 patients (48.4\%) were randomised to placebo.

Table 2 and supplementary table $\mathrm{C}$ show the pooled estimates for the outcome of doubling of serum creatinine levels in network meta-analysis. Figure 3 shows the distribution of probabilities for each treatment being ranked at different positions for the outcome of doubling of serum creatinine levels. ACE inhibitors showed a statistical significance in reducing the incidence of doubled serum creatinine levels compared with either placebo (odds ratio $0.58,95 \%$ credible interval 0.32 to $0.90)$ or $\beta$ blockers $(0.12,0.02$ to 0.74$)$. Comparisons among other treatment strategies, such as ACE inhibitors versus ARBs, did not show significant differences. ACE inhibitors showed the greatest probability $(79.5 \%)$ of being the best treatment, followed by ARBs, with the highest probability (63.7\%) of being ranked the second. $\beta$ blockers had the highest probability $(88.9 \%)$ of being in the last ranking position.

\section{Comparisons between traditional pairwise and bayesian network meta-analyses}

Figure $4 \Downarrow$ and supplementary table $\mathrm{C}$ show the results of traditional pairwise and bayesian network meta-analyses. Although the point estimates showed small differences, the confidence intervals from traditional pairwise meta-analyses and the credible intervals from bayesian network meta-analyses in general overlapped. The node splitting method showed no significant inconsistency within the networks for any of the three outcomes (see supplementary table D).

\section{Discussion}

In this network meta-analysis reviewing the efficacy of different antihypertensive treatment strategies on survival and major renal outcomes in patients with diabetes, we found that therapy with angiotensin converting enzyme (ACE) inhibitor therapy is the only significantly effective treatment in preventing the doubling of serum creatinine levels compared with placebo. Our analysis also shows the significant inferiority of $\beta$ blockers in all cause mortality. Although the beneficial effects of ACE inhibitors compared with angiotensin receptor blockers (ARBs) did not reach statistical significance, ACE inhibitors consistently showed higher probabilities of being at the superior ranking positions among all outcomes. The protective effect of ACE inhibitor plus calcium channel blocker compared with placebo was not statistically significant, yet this combination therapy showed the greatest probability of being the best treatment option in reducing mortality. These estimates are fairly robust and changed little in sensitivity analyses.

\section{Strengths of this study}

Until more evidences of direct active comparisons are reported, our network meta-analysis provides a useful and complete picture for the propensity of antihypertensive treatments associated with major outcomes among hypertensive patients with diabetes. This statistical technique not only includes the results of direct comparisons but also incorporates indirect comparisons, particularly for ACE inhibitors versus ARBs, which have been rarely compared in head to head trials. Furthermore, the results in effect estimates are highly coherent and robust. As the differences in treatment effects among those antihypertensive drugs except for $\beta$ blockers were generally small, we also reported the probabilities of ranking for these treatments, and this is only attainable by using a bayesian approach.

\section{Results in relation to other studies and reviews}

Our study results are consistent with those of previous pairwise meta-analyses, but the network meta-analysis incorporates both direct and indirect comparisons of treatment strategies, including those that have never been compared directly. A previous meta-analysis showed that both ACE inhibitors (relative risk $0.71,95 \%$ confidence interval 0.56 to 0.91$)$ and ARBs $(0.79$, 0.68 to 0.91 ) were associated with a reduction in the risk of serum creatinine levels being doubled, and ARBs were associated with a reduced risk of end stage renal disease $(0.78$, 0.67 to 0.91 ); but neither ACE inhibitors $(0.96,0.85$ to 1.09 ) nor ARBs $(0.99,0.85$ to 1.16$)$ affected all cause mortality in patients with diabetes. ${ }^{3}$ Similarly, Strippoli and colleagues showed that both ACE inhibitors and ARBs reduced the risk of end stage renal disease or doubling of serum creatinine levels, and only full dose ACE inhibitors (relative risk $0.78,95 \%$ confidence interval 0.61 to 0.98 ) were associated with a reduction in all cause mortality among patients with diabetes; however, the relative effects of ACE inhibitors versus ARBs could not be obtained owing to the lack of adequate studies of direct comparisons. ${ }^{4}$ Our network meta-analysis uses a much broader evidence base and includes a large number of studies, with 11 different treatment strategies. By including several recent large trials on patients with diabetes (such as the ROADMAP, DIRECT, and ADVANCE studies), ${ }^{31-35}$ our meta-analysis provides updated evidence that can be more appropriately integrated into relevant clinical guidelines.

Previous studies showed that ACE inhibitors block the renin-angiotensin system, decrease glomerular capillary pressure by inducing vasodilation of efferent arterioles, reduce the level of albuminuria, slow the progression of chronic kidney disease, and lower the risk of cardiovascular diseases. ${ }^{30}{ }^{36}$ Moreover, the results of clinical trials and meta-analyses suggest that ACE inhibitors provide renoprotective effects in diabetic nephropathy above and beyond any such effect attributable to a reduction in blood pressure ${ }^{15}$; this may be caused by the non-haemodynamic antiproteinuric effects of ACE inhibitors, such as enhanced selectivity of the glomerular barrier, compensatory growth of residual nephrons, and the limitation of interstitial inflammation and fibrosis. ${ }^{37} 38$

As a group of pharmaceuticals that modulate the renin-angiotensin system, ARBs selectively block the activation of angiotensin II AT1 receptors and are considered to have 
similar cardioprotective and renoprotective effects as ACE inhibitors. ${ }^{49}$ Although current guidelines suggest the equivalent protective effects of ACE inhibitors and ARBs for hypertensive patients with diabetes, some of the guidelines prefer ACE inhibitors as the first line treatment on the grounds of cost and suggest that ARBs should be substituted mainly under the condition of intolerance to ACE inhibitors or when a low cost generic ARB is available. ${ }^{8}{ }^{10}$ Because of AT1 blockade, ARBs upregulate the AT2 receptors; however, some recent studies suggest that the overstimulation of AT2 receptors may be less beneficial than previously proposed and might even contribute to cardiac hypertrophy, vascular fibrosis, and a decrease of neovascularisation in hypoxic myocardial tissues. ${ }^{40}$ At present, whether ARBs increase cardiovascular morbidity or mortality remains controversial among clinical studies. ${ }^{41}{ }^{42}$ Several large scale placebo controlled trials for diabetic nephropathy, the Irbesartan Diabetic Nephropathy Trial, ROADMAP, and Olmesartan Reducing Incidence of End Stage Renal Disease in Diabetic Nephropathy Trial, have all shown a higher rate of cardiovascular death among patients randomised to the ARB group. ${ }^{3143}$ Concerned about drug safety, the US Food and Drug Administration is currently reviewing existing data, and additional studies are underway (for example, www.fda.gov/ Drugs/DrugSafety/ucm251268.htm). On the other hand, the largest trial comparing ACE inhibitors with ARBs, the Ongoing Telmisartan Alone and in Combination with Ramipril Global Endpoint Trial, showed equivalent cardiorenoprotective effects of both renin-angiotensin system blockers in patients with high risk cardiovascular disease or diabetes. ${ }^{45}$ Nevertheless, participants in that trial were not randomised based on the presence of diabetes or the severity of nephropathy. ${ }^{45}$ Although our study showed that ACE inhibitors had higher probabilities than ARBs to be in the superior ranking positions for all three outcomes, the differences between ACE inhibitors and ARBs did not reach statistical significance. Furthermore, combination therapies such as ARB plus calcium channel blocker, ARB plus diuretic, and ACE inhibitor plus ARB could not be evaluated owing to patient numbers and events in those treatment arms being too few. Therefore whether ARBs are actually equivalent to ACE inhibitors for protective effects, as well as for cost effectiveness, deserves further research. As a result, since current evidence is not able to show a better protective effect for ARBs compared with ACE inhibitors, our findings support the use of ACE inhibitors as the first line antihypertensive agent when cost is a concern.

As calcium channel blockers have been shown to reduce afferent arteriolar pressure and to interfere with glomerular mesangial cell growth, ${ }^{46}{ }^{47}$ combining an ACE inhibitor with a calcium channel blocker is able to provide a greater reduction in intraglomerular pressure and albuminuria than either drug alone. ${ }^{38}$ Observations in the coronary system of the dog have shown that either an ACE inhibitor or calcium channel blocker stimulates nitric oxide production; and their combination seems to produce a synergistic effect on endothelial function, suggesting that this therapy could be beneficial in preventing or stabilising atherosclerosis. ${ }^{48}$ Recent clinical studies and meta-analyses have shown that a combination therapy of ACE inhibitor with calcium channel blocker effectively reduces blood pressure and provides vasculoprotective effects while minimising the adverse effects from individual drugs. ${ }^{49-51}$ These clinical and experimental evidences are compatible with our findings and may explain why the combination therapy of ACE inhibitor plus calcium channel blocker showed the greatest probability of being the best treatment options for reducing all cause mortality in patients with diabetes. However, the renal outcomes on diabetic nephropathy from therapy of ACE inhibitor plus calcium channel blocker could not be evaluated in our current analysis since no available trial fulfilled our inclusion criteria.

Diuretics effectively decrease plasma volume and lower blood pressure in patients with diabetes. On the other hand, the use of diuretics is also associated with negative metabolic effects such as stimulation of the renin-angiotensin system, electrolyte imbalance, and worsened glycaemic control ${ }^{52}{ }^{53}$; recent guidelines from the European Society of Cardiology do not recommend the use of diuretics as the first line antihypertensive agents in patients with diabetes. ${ }^{54}$ Compared with monotherapy, the combination treatment of ACE inhibitor plus diuretic offers better control of blood pressure and may contribute to a reduction in cardiovascular events. ${ }^{33}$ However, this combination may cause volume depletion and inadequate glomerular perfusion in patients with impaired renal function and result in a reduced glomerular filtration rate and raised serum creatinine levels. ${ }^{49}$ The difference between the cardiovascular and renal effects reported among previous studies may explain the discordant results in ranking orders for all cause mortality and renal outcomes in our analysis for ACE inhibitor plus diuretic.

In previous clinical trials and meta-analyses, $\beta$ blockers have often shown unfavourable outcomes compared with other antihypertensive treatments in patients, including higher all cause and cardiovascular mortality, more stroke events, or increased risk of new onset diabetes. ${ }^{55-59}$ In a previous meta-analysis of $\beta$ blockers for the management of hypertension in patients with diabetes, the study concluded that $\beta$ blockers increase the risk for cardiovascular mortality when compared with renin-angiotensin system blockers (relative risk 1.39, 95\% confidence interval 1.07 to 1.80$).{ }^{55}$ Regression of left ventricular hypertrophy is more closely correlated with central blood pressure than brachial blood pressure. ${ }^{58} \beta$ blockers do not lower central blood pressure as much as other antihypertensive treatments, together with the negative metabolic effects caused by $\beta$ blockers, which may explain the worse cardiovascular outcomes of this class of drugs. ${ }^{58} 60$

\section{Limitations of this study}

Our findings have several limitations. Firstly, variations of drug ingredients or doses, whether as monotherapy or combinations, may contribute to variations in study outcomes. However, treating different doses of the same drug or different drug ingredients as different treatment regimens would not be feasible owing to insufficient patient numbers and events to form a well connected network, so we only evaluated treatment effects of major drug classes. Besides, we found no significant heterogeneity in our traditional meta-analyses and no substantial inconsistency in our network meta-analyses. Secondly, we did not analyse the treatment effects on the change of albuminuria level, although many included studies were designed to analyse the reduction in albuminuria as their primary renal outcomes. Reduction in albuminuria is only a surrogate marker for renal outcomes, ${ }^{5}$ and current guidelines suggest the use of renin-angiotensin system blockers for any degree of albuminuria among hypertensive patients with diabetes. ${ }^{1}$ In addition, further stratification by the levels of albuminuria might lead to insufficient statistical power in the analyses. Thus we used the risks of end stage renal disease and doubling of serum creatinine level as more solid renal outcomes in our analyses. Thirdly, we did not analyse the influences of blood pressure reduction among different antihypertensive treatments since the blood pressure data in this systematic review was heterogeneous. Blood pressure measurements are biased if the observer or the patient 
is not blinded to the allocated treatment, and the decrease in blood pressure is usually greater in trials of patients with higher blood pressure at baseline. ${ }^{61}$ Moreover, previous network meta-analyses have shown that various antihypertensive treatments were associated with only slightly different degrees of blood pressure lowering, and evidence is growing that effects on health outcomes with antihypertensive therapies are often beyond or independent of blood pressure reduction. ${ }^{556162}$ Therefore, the problems of blood pressure reduction did not seem to have a significant influence on our analyses. Fourthly, for reduction in mortality, therapy using the combination of ACE inhibitor with calcium channel blocker showed the highest probability of being the best treatment, and this result was fairly robust across all sensitivity analyses. Nevertheless, since only $1.7 \%$ of the study participants were randomised to this combination therapy, interpretations of the results should still be cautious about the external generalisability. Fifthly, many of the included studies showed low event rates or even no events in one or both treatment arms. Although studies with zero events do not cause computational problems with a bayesian approach as it usually does with traditional frequentist methods, those studies increase the uncertainty in the comparisons of multiple treatments within a network meta-analysis. This is why our analyses showed wide credible intervals for several treatment comparisons, as event rates in trials involving those treatments were low. Finally, some patient characteristics and methodological quality, such as age, sex, cardiovascular diseases, as well as selection bias or performance bias, might be potential confounders for our analyses. However, metaregression or subgroup analysis in network meta-analysis is much more complex and the statistical power is relatively low, especially when comparing many treatment strategies with relatively low event rates, such as the case in our study. Whether those patient characteristics or methodological quality have substantial influences on treatment outcomes deserves further studies in the future.

\section{Conclusions}

Our analyses show the renoprotective effects and superiority of using ACE inhibitors in patients with diabetes, and also show the harmful effects of $\beta$ blockers. The available evidence is not able to show a better protective effect for ARBs compared with ACE inhibitors. Considering the cost of drugs, our findings support the use of ACE inhibitors as the first line antihypertensive agent in patients with diabetes. Calcium channel blockers might be the preferred treatment in combination with ACE inhibitors if adequate blood pressure control cannot be achieved by ACE inhibitors alone.

Contributors: Y-KT and K-LC contributed equally to this work. All authors had full access to all of the data in the study and take responsibility for the integrity of the data and the accuracy of the data analysis. $\mathrm{H}-\mathrm{YW}$, J-WH, K-YH, K-DW, Y-KT, and K-LC conceived and designed the experiments. H-YW, J-WH, Y-SP, Y-KT, and K-LC enrolled patients. $\mathrm{H}-\mathrm{YW}, \mathrm{J}-\mathrm{WH}, \mathrm{H}-\mathrm{JL}, \mathrm{W}-\mathrm{CL}, \mathrm{Y}-\mathrm{SP}$, and Y-KT performed the experiments. $\mathrm{H}-\mathrm{YW}, \mathrm{J}-\mathrm{WH}, \mathrm{H}-\mathrm{JL}, \mathrm{W}-\mathrm{CL}, \mathrm{Y}-\mathrm{SP}, \mathrm{Y}-\mathrm{KT}$, and K-LC analysed the data. J-WH, Y-SP, K-YH, K-DW, Y-KT, and K-LC contributed reagents, materials, or analysis tools. H-YW, J-WH, H-JL, Y-KT, and K-LC wrote the first draft of the manuscript. W-CL, Y-SP, K-YH, K-DW, Y-KT, and K-LC contributed to the writing of the manuscript. All authors met the ICMJE criteria for authorship. All authors agree with the manuscript results and conclusions. Y-KT and K-LC are the guarantors.

Funding: None received.

Competing interests: All authors have completed the ICMJE uniform disclosure form at www.icmje.org/coi_disclosure.pdf (available on request from the corresponding author) and declare no support from any organisation for the submitted work; no financial relationships with any organisations that might have an interest in the submitted work in the previous three years; and no other relationships or activities that could appear to have influenced the submitted work.

\section{Ethical approval: Not required.}

Data sharing: No additional data available.

Standards of medical care in diabetes-2013. Diabetes Care 2013:36(Suppl 1):S11-66.

KDOQI Clinical Practice Guidelines and Clinical Practice Recommendations for Diabetes and Chronic Kidney Disease. Am J Kidney Dis 2007;49:S12-154.

3 Sarafidis PA, Stafylas PC, Kanaki AI, Lasaridis AN. Effects of renin-angiotensin system blockers on renal outcomes and all-cause mortality in patients with diabetic nephropathy: an updated meta-analysis. Am J Hypertens 2008;21:922-9.

4 Strippoli GF, Bonifati C, Craig M, Navaneethan SD, Craig JC. Angiotensin converting enzyme inhibitors and angiotensin II receptor antagonists for preventing the progression of diabetic kidney disease. Cochrane Database Syst Rev 2006:CD006257.

5 Strippoli GF, Craig M, Schena FP, Craig JC. Antihypertensive agents for primary prevention of diabetic nephropathy. J Am Soc Nephrol 2005;16:3081-91.

6 Chobanian AV, Bakris GL, Black HR, Cushman WC, Green LA, Izzo JL, Jr., et al. Seventh report of the Joint National Committee on Prevention, Detection, Evaluation, and Treatment of High Blood Pressure. Hypertension 2003;42:1206-52.

7 Mancia G, De Backer G, Dominiczak A, Cifkova R, Fagard R, Germano G, et al. 2007 Guidelines for the Management of Arterial Hypertension: The Task Force for the Management of Arterial Hypertension of the European Society of Hypertension (ESH) and of the European Society of Cardiology (ESC). J Hypertens 2007;25:1105-87.

8 Type 2 Diabetes: National Clinical Guideline for Management in Primary and Secondary Care (Update). London: Royal College of Physicians of London; 2008.

9 Guidelines for the management of absolute cardiovascular disease risk. Australia: National Vascular Disease Prevention Alliance; 2012.

10 Hypertension: The Clinical Management of Primary Hypertension in Adults: Update of Clinical Guidelines 18 and 34. London: National Clinical Guideline Centre.; 2011.

11 Lumley T. Network meta-analysis for indirect treatment comparisons. Stat Med 2002;21:2313-24.

12 Lu G, Ades AE. Combination of direct and indirect evidence in mixed treatment comparisons. Stat Med 2004;23:3105-24.

13 Bucher HC, Guyatt GH, Griffith LE, Walter SD. The results of direct and indirect treatment comparisons in meta-analysis of randomized controlled trials. J Clin Epidemiol 1997;50:683-91.

14 Sciarretta S, Palano F, Tocci G, Baldini R, Volpe M. Antihypertensive treatment and development of heart failure in hypertension: a Bayesian network meta-analysis of studies in patients with hypertension and high cardiovascular risk. Arch Intern Med 2011;171:384-94.

15 Wandel S, Juni P, Tendal B, Nuesch E, Villiger PM, Welton NJ, et al. Effects of glucosamine, chondroitin, or placebo in patients with osteoarthritis of hip or knee: network meta-analysis. BMJ 2010;341:c4675.

16 Tu YK, Needleman I, Chambrone L, Lu HK, Faggion CM, Jr. A Bayesian network meta-analysis on comparisons of enamel matrix derivatives, guided tissue regeneration and their combination therapies. J Clin Periodontol 2012;39:303-14.

17 Salanti G, Higgins JP, Ades AE, loannidis JP. Evaluation of networks of randomized trials. Stat Methods Med Res 2008;17:279-301.

18 Higgins J, Green S. Cochrane Handbook for Systematic Reviews of Interventions Version 5.1.0 [updated March 2011]. The Cochrane Collaboration, 2011; Available from www. cochrane-handbook.org. Accessed Oct 1, 2011.

19 Begg CB, Mazumdar M. Operating characteristics of a rank correlation test for publication bias. Biometrics 1994;50:1088-101.

20 Egger M, Davey Smith G, Schneider M, Minder C. Bias in meta-analysis detected by a simple, graphical test. BMJ 1997:315:629-34.

21 Brooks SP, Gelman A. Alternative methods for monitoring convergence of iterative simulations. J Comput Graph Stat 1998;7:434-45.

22 Lu G, Ades AE. Assessing evidence inconsistency in mixed treatment comparisons. J Am Stat Assoc 2006;101:477-59.

23 Dias S, Welton NJ, Caldwell DM, Ades AE. Checking consistency in mixed treatment comparison meta-analysis. Stat Med 2010:29:932-44.

24 Cipriani A, Furukawa TA, Salanti G, Geddes JR, Higgins JP, Churchill R, et al. Comparative efficacy and acceptability of 12 new-generation antidepressants: a multiple-treatments meta-analysis. Lancet 2009;373:746-58.

25 van der Valk R, Webers CA, Lumley T, Hendrikse F, Prins MH, Schouten JS. A network meta-analysis combined direct and indirect comparisons between glaucoma drugs to rank effectiveness in lowering intraocular pressure. J Clin Epidemiol 2009:62:1279-83.

26 Hartling L, Fernandes RM, Bialy L, Milne A, Johnson D, Plint A, et al. Steroids and bronchodilators for acute bronchiolitis in the first two years of life: systematic review and meta-analysis. BMJ 2011;342:d1714.

27 Katayama K, Nomura S, Ishikawa H, Murata T, Koyabu S, Nakano T. Comparison between valsartan and valsartan plus cilnidipine in type II diabetics with normo- and microalbuminuria. Kidney Int 2006;70:151-6.

28 Kohlmann O, Jr., Roca-Cusachs A, Laurent S, Schmieder RE, Wenzel RR, Fogari R. Fixed-dose manidipine/delapril versus losartan/hydrochlorothiazide in hypertensive patients with type 2 diabetes and microalbuminuria. Adv Ther 2009;26:313-24.

29 Mehdi UF, Adams-Huet B, Raskin P, Vega GL, Toto RD. Addition of angiotensin receptor blockade or mineralocorticoid antagonism to maximal angiotensin-converting enzyme inhibition in diabetic nephropathy. J Am Soc Nephrol 2009;20:2641-50.

30 Marre M, Lievre M, Chatellier G, Mann JF, Passa P, Menard J. Effects of low dose ramipril on cardiovascular and renal outcomes in patients with type 2 diabetes and raised excretion of urinary albumin: randomised, double blind, placebo controlled trial (the DIABHYCAR study). BMJ 2004;328:495.

31 Haller $\mathrm{H}$, Ito S, Izzo JL, Jr., Januszewicz A, Katayama S, Menne J, et al. Olmesartan for the delay or prevention of microalbuminuria in type 2 diabetes. $N$ Engl $J$ Med 2011;364:907-17.

32 de Galan BE, Perkovic V, Ninomiya T, Pillai A, Patel A, Cass A, et al. Lowering blood pressure reduces renal events in type 2 diabetes. J Am Soc Nephrol 2009;20:883-92. 


\section{What is already known on this topic}

Guidelines suggest angiotensin converting enzyme (ACE) inhibitors or angiotensin receptor blockers (ARBs) as the first line treatment in hypertensive patients with diabetes when cost is not a concern

Clinical trials comparing an ACE inhibitor with an ARB are rare, and the difference in protective effects between these drugs for patients with diabetes remains inconclusive

No consensus exists about the choice of treatments in combination with renin-angiotensin system blockers in patients with diabetes

\section{What this study adds}

By combining direct and indirect evidence, our analyses show the renoprotective effects and superiority of ACE inhibitors in patients with diabetes, and also show the harmful effects of $\beta$ blockers

As the available evidence is not able to show a better protective effect for ARBs compared with ACE inhibitors, our findings support the use of ACE inhibitors as the first line antihypertensive agent in consideration of cost

Calcium channel blockers might be the preferred treatment in combination with ACE inhibitors if adequate blood pressure control is unachievable by ACE inhibitors alone in patients with diabetes

33 Patel A, MacMahon S, Chalmers J, Neal B, Woodward M, Billot L, et al. Effects of a fixed combination of perindopril and indapamide on macrovascular and microvascular outcomes in patients with type 2 diabetes mellitus (the ADVANCE trial): a randomised controlled trial. Lancet 2007;370:829-40.

34 Chaturvedi N, Porta M, Klein R, Orchard T, Fuller J, Parving HH, et al. Effect of candesartan on prevention (DIRECT-Prevent 1) and progression (DIRECT-Protect 1) of retinopathy in type 1 diabetes: randomised, placebo-controlled trials. Lancet 2008;372:1394-402.

35 Sjolie AK, Klein R, Porta M, Orchard T, Fuller J, Parving HH, et al. Effect of candesartan on progression and regression of retinopathy in type 2 diabetes (DIRECT-Protect 2): a randomised placebo-controlled trial. Lancet 2008:372:1385-93.

36 Effects of ramipril on cardiovascular and microvascular outcomes in people with diabetes mellitus: results of the HOPE study and MICRO-HOPE substudy. Heart Outcomes Prevention Evaluation Study Investigators. Lancet 2000;355:253-9.

37 Abbate M, Zoja C, Rottoli D, Corna D, Perico N, Bertani T, et al. Antiproteinuric therapy while preventing the abnormal protein traffic in proximal tubule abrogates protein- and complement-dependent interstitial inflammation in experimental renal disease. J Am Soc Nephrol 1999;10:804-13.

38 Fogari R, Preti P, Zoppi A, Rinaldi A, Corradi L, Pasotti C, et al. Effects of amlodipine fosinopril combination on microalbuminuria in hypertensive type 2 diabetic patients. Am $J$ Hypertens 2002;15:1042-9.

39 Ram CV. Reappraisal of role of angiotensin receptor blockers in cardiovascular protection. Vasc Health Risk Manag 2011;7:315-9.

40 Levy BI. Can angiotensin II type 2 receptors have deleterious effects in cardiovascular disease? Implications for therapeutic blockade of the renin-angiotensin system. Circulation 2004;109:8-13.

41 Strauss MH, Hall AS. Angiotensin receptor blockers may increase risk of myocardial infarction: unraveling the ARB-MI paradox. Circulation 2006;114:838-54.

42 Tsuyuki RT, McDonald MA. Angiotensin receptor blockers do not increase risk of myocardial infarction. Circulation 2006;114:855-60.

43 Berl T, Hunsicker LG, Lewis JB, Pfeffer MA, Porush JG, Rouleau JL, et al. Cardiovascular outcomes in the Irbesartan Diabetic Nephropathy Trial of patients with type 2 diabetes and overt nephropathy. Ann Intern Med 2003;138:542-9.

44 Imai E, Chan JC, Ito S, Yamasaki T, Kobayashi F, Haneda M, et al. Effects of olmesartan on renal and cardiovascular outcomes in type 2 diabetes with overt nephropathy: a multicentre, randomised, placebo-controlled study. Diabetologia 2011:54-2978-86.

45 Mann JF, Schmieder RE, McQueen M, Dyal L, Schumacher H, Pogue J, et al. Renal outcomes with telmisartan, ramipril, or both, in people at high vascular risk (the ONTARGET study): a multicentre, randomised, double-blind, controlled trial. Lancet 2008;372:547-53.

46 Orth SR, Nobiling R, Bonisch S, Ritz E. Inhibitory effect of calcium channel blockers on human mesangial cell growth: evidence for actions independent of $\mathrm{L}$-type $\mathrm{Ca} 2+$ channels. Kidney Int 1996;49:868-79.

47 Loutzenhiser R, Epstein M. Effects of calcium antagonists on renal hemodynamics. Am $J$ Physiol 1985;249:F619-29.

48 Jamerson KA, Bakris GL, Wun CC, Dahlof B, Lefkowitz M, Manfreda S, et al. Rationale and design of the avoiding cardiovascular events through combination therapy in patients living with systolic hypertension (ACCOMPLISH) trial: the first randomized controlled trial to compare the clinical outcome effects of first-line combination therapies in hypertension. Am J Hypertens 2004;17:793-801.

49 Bakris GL, Sarafidis PA, Weir MR, Dahlof B, Pitt B, Jamerson K, et al. Renal outcomes with different fixed-dose combination therapies in patients with hypertension at high risk for cardiovascular events (ACCOMPLISH): a prespecified secondary analysis of a randomised controlled trial. Lancet 2010;375:1173-81.

50 Weber MA, Bakris GL, Jamerson K, Weir M, Kjeldsen SE, Devereux RB, et al. Cardiovascular events during differing hypertension therapies in patients with diabetes. J Am Coll Cardiol 2010;56:77-85.

51 Lv Y, Zou Z, Chen GM, Jia HX, Zhong J, Fang WW. Amlodipine and angiotensin-converting enzyme inhibitor combination versus amlodipine monotherapy in hypertension: a meta-analysis of randomized controlled trials. Blood Press Monit 2010;15:195-204.

52 Major outcomes in high-risk hypertensive patients randomized to angiotensin-converting enzyme inhibitor or calcium channel blocker vs diuretic: The Antihypertensive and Lipid-Lowering Treatment to Prevent Heart Attack Trial (ALLHAT). JAMA 2002;288:2981-97.

53 Elliott WJ, Meyer PM. Incident diabetes in clinical trials of antihypertensive drugs: a network meta-analysis. Lancet 2007;369:201-7.

54 Graham I, Atar D, Borch-Johnsen K, Boysen G, Burell G, Cifkova R, et al. European guidelines on cardiovascular disease prevention in clinical practice: full text. Fourth Joint Task Force of the European Society of Cardiology and other societies on cardiovascular disease prevention in clinical practice (constituted by representatives of nine societies and by invited experts). Eur J Cardiovasc Prev Rehabil 2007;14(Suppl 2):S1-113.

55 Balamuthusamy S, Molnar J, Adigopula S, Arora R. Comparative analysis of beta-blockers with other antihypertensive agents on cardiovascular outcomes in hypertensive patients with diabetes mellitus: a systematic review and meta-analysis. Am J Ther 2009;16:133-42.

56 Wiysonge CS, Bradley H, Mayosi BM, Maroney R, Mbewu A, Opie LH, et al. Beta-blockers for hypertension. Cochrane Database Syst Rev 2007:CD002003.

57 Cutler JA, Davis BR. Thiazide-type diuretics and beta-adrenergic blockers as first-line drug treatments for hypertension. Circulation 2008;117:2691-704; discussion 705.

58 Lindholm LH, Carlberg B, Samuelsson O. Should beta blockers remain first choice in the treatment of primary hypertension? A meta-analysis. Lancet 2005;366:1545-53.

59 Carlberg B, Samuelsson O, Lindholm LH. Atenolol in hypertension: is it a wise choice? Lancet 2004:364:1684-9.

60 Klingbeil AU, Schneider M, Martus P, Messerli FH, Schmieder RE. A meta-analysis of the effects of treatment on left ventricular mass in essential hypertension. Am J Med 2003;115:41-6.

61 Wright JM, Musini VM. First-line drugs for hypertension. Cochrane Database Syst Rev 2009:CD001841.

62 Psaty BM, Lumley T, Furberg CD, Schellenbaum G, Pahor M, Alderman MH, et al. Health outcomes associated with various antihypertensive therapies used as first-line agents: a network meta-analysis. JAMA 2003;289:2534-44.

\section{Accepted: 22 September 2013}

\section{Cite this as: BMJ 2013;347:f6008}

This is an Open Access article distributed in accordance with the Creative Commons Attribution Non Commercial (CC BY-NC 3.0) license, which permits others to distribute, remix, adapt, build upon this work non-commercially, and license their derivative works on different terms, provided the original work is properly cited and the use is non-commercial. See: http://creativecommons.org/licenses/by-nc/3.0/. 


\section{Tables}

\begin{tabular}{|c|c|c|c|c|c|c|c|c|c|c|c|}
\hline \multirow[b]{2}{*}{ Trial } & \multirow[b]{2}{*}{$\begin{array}{l}\text { Follow-up } \\
\text { (years) }\end{array}$} & \multirow[b]{2}{*}{$\begin{array}{l}\text { No of } \\
\text { patients }\end{array}$} & \multirow[b]{2}{*}{$\begin{array}{l}\text { Mean } \\
\text { age } \\
\text { (years) }\end{array}$} & \multirow[b]{2}{*}{$\begin{array}{c}\text { Female } \\
\text { (\%) }\end{array}$} & \multirow[b]{2}{*}{$\begin{array}{l}\text { Type of } \\
\text { diabetes }\end{array}$} & \multirow[b]{2}{*}{$\begin{array}{c}\text { Level of } \\
\text { albuminuria* }\end{array}$} & \multirow[b]{2}{*}{ Treatment } & \multirow[b]{2}{*}{$\begin{array}{l}\text { Change in } \\
\text { MAP (mm } \\
\mathrm{Hg})\end{array}$} & \multicolumn{3}{|c|}{ Outcomes } \\
\hline & & & & & & & & & $\begin{array}{l}\text { All cause } \\
\text { mortality }\end{array}$ & $\begin{array}{l}\text { End } \\
\text { stage } \\
\text { renal } \\
\text { disease }\end{array}$ & $\begin{array}{l}\text { Doubling } \\
\text { of serum } \\
\text { creatinine }\end{array}$ \\
\hline Parving et al 1989 & 1.0 & 32 & 30.9 & 28.1 & 1 & Macro & $\begin{array}{l}\text { ACE inhibitor; } \\
\text { placebo }\end{array}$ & $-2.6 ; 5.7$ & $1 / 15 ; 1 / 17$ & $1 / 15 ; 3 / 17$ & $2 / 15 ; 3 / 17$ \\
\hline Bauer et al 1992 & 1.5 & 33 & 50.0 & 27.3 & Mixed & Macro & $\begin{array}{l}\text { ACE inhibitor; } \\
\text { placebo }\end{array}$ & $-0.7 ; 0.01$ & $1 / 18 ; 0 / 15$ & $1 / 18 ; 0 / 15$ & - \\
\hline Björck et al 1992 & 2.2 & 40 & - & - & 1 & Macro & $\begin{array}{l}\text { ACE inhibitor; } \beta \\
\text { blocker }\end{array}$ & $-12.0 ;-6.0$ & $0 / 22 ; 0 / 18$ & $2 / 22 ; 2 / 18$ & - \\
\hline Chan et al 1992 & 1.0 & 102 & 58.1 & 59.8 & 2 & Mixed & $\begin{array}{l}\text { ACE inhibitor; } \\
\text { CCB }\end{array}$ & $-22.0 ;-21.0$ & $1 / 50 ; 0 / 52$ & - & - \\
\hline Chase et al 1993 & 2.0 & 16 & 20.8 & 25.0 & 1 & Micro & $\begin{array}{l}\text { ACE inhibitor; } \\
\text { placebo }\end{array}$ & $3.3 ; 1.0$ & $0 / 7 ; 0 / 9$ & - & - \\
\hline Hallab et al 1993 & 1.0 & 25 & 37.6 & 44.0 & 1 & Micro & $\begin{array}{l}\text { ACE inhibitor; } \\
\text { diuretic }\end{array}$ & $8.0 ; 5.0$ & $0 / 13 ; 0 / 12$ & - & - \\
\hline Lewis et al 1993 & 3.0 & 409 & 34.5 & 47.2 & 1 & Macro & $\begin{array}{l}\text { ACE inhibitor; } \\
\text { placebo }\end{array}$ & $-6.0 ;-4.0$ & $8 / 207 ; 14 / 202$ & $\begin{array}{l}\text { 20/207; } \\
31 / 202 \\
\end{array}$ & $\begin{array}{l}25 / 207 \\
43 / 202\end{array}$ \\
\hline $\begin{array}{l}\text { O'Donnell et al } \\
1993\end{array}$ & 1.0 & 32 & 48.7 & 28.1 & Mixed & Micro & $\begin{array}{l}\text { ACE inhibitor; } \\
\text { placebo }\end{array}$ & $-3.7 ;-1.3$ & $0 / 15 ; 0 / 17$ & - & - \\
\hline Ravid et al 1993 & 5.0 & 108 & 44.1 & 61.1 & 2 & Micro & $\begin{array}{l}\text { ACE inhibitor; } \\
\text { placebo }\end{array}$ & $1.0 ; 5.0$ & $0 / 56 ; 0 / 52$ & $0 / 56 ; 0 / 52$ & $\begin{array}{l}2 / 56 \\
12 / 52\end{array}$ \\
\hline Bakris et al 1994 & 1.5 & 15 & 26.6 & 53.3 & 1 & Micro & $\begin{array}{l}\text { ACE inhibitor; } \\
\text { placebo }\end{array}$ & $-10.0 ; 0$ & $0 / 8 ; 0 / 7$ & 一 & - \\
\hline Capek et al 1994 & 1.0 & 20 & 63.6 & 65.0 & 2 & Micro & $\begin{array}{l}\text { ACE inhibitor; } \\
\text { placebo }\end{array}$ & $-3.0 ; 1.7$ & $0 / 10 ; 0 / 10$ & $0 / 10 ; 0 / 10$ & $0 / 10 ; 0 / 10$ \\
\hline Elving et al 1994 & 2.0 & 30 & 38.0 & 23.3 & 1 & Macro & $\begin{array}{l}\text { ACE inhibitor; } \beta \\
\text { blocker }\end{array}$ & $-10.0 ;-4.0$ & $0 / 15 ; 0 / 15$ & - & - \\
\hline Sano et al 1994 & 4.0 & 52 & 64.0 & - & 2 & Micro & $\begin{array}{l}\text { ACE inhibitor; } \\
\text { placebo }\end{array}$ & $0.3 ;-2.6$ & $1 / 26 ; 0 / 26$ & - & - \\
\hline Laffel et al 1995 & 2.0 & 143 & 32.7 & 49.7 & 1 & Micro & $\begin{array}{l}\text { ACE inhibitor; } \\
\text { placebo }\end{array}$ & $-8.7 ; 2.0$ & $1 / 70 ; 0 / 73$ & - & - \\
\hline Bakris et al 1996 & 6.0 & 52 & 62.1 & 50.0 & 2 & Macro & $\begin{array}{l}\text { ACE inhibitor; } \\
\text { CCB; } \beta \text { blocker }\end{array}$ & $\begin{array}{c}-16.0 ; \\
-18.0 ;-15.0\end{array}$ & $\begin{array}{c}1 / 18 ; 1 / 18 \\
4 / 16 \\
\end{array}$ & - & $\begin{array}{c}1 / 18 ; 2 / 18 ; \\
5 / 16\end{array}$ \\
\hline Viberti et al 1996 & 2.0 & 235 & 32.2 & 47.7 & 1 & Micro & $\begin{array}{l}\text { ACE inhibitor; } \\
\text { placebo }\end{array}$ & $-3.3 ; 1.0$ & $1 / 116 ; 1 / 119$ & - & - \\
\hline Nielsen et al 1997 & 3.5 & 43 & 60.5 & 44.2 & 2 & Macro & $\begin{array}{l}\text { ACE inhibitor; } \beta \\
\text { blocker }\end{array}$ & $-11.7 ;-10.0$ & $1 / 21 ; 5 / 22$ & $1 / 21 ; 1 / 22$ & - \\
\hline ABCD 1998 & 5.0 & 470 & 57.5 & 32.6 & 2 & $\begin{array}{l}\text { Micro and } \\
\text { macro }\end{array}$ & $\begin{array}{l}\text { ACE inhibitor; } \\
\text { CCB }\end{array}$ & - & $\begin{array}{l}13 / 235 \\
17 / 235\end{array}$ & - & - \\
\hline Bakris et al 1998 & 1.0 & 44 & 59.7 & 43.2 & 2 & Macro & $\begin{array}{l}\text { ACE } \\
\text { inhibitor+CCB; } \\
\text { ACE inhibitor; } \\
\text { CCB }\end{array}$ & $\begin{array}{c}-26.0 \\
-21.0 ;-25.3\end{array}$ & $\begin{array}{c}0 / 16 ; 0 / 14 \\
0 / 14\end{array}$ & - & - \\
\hline $\begin{array}{l}\text { Crepaldi et al } \\
1998\end{array}$ & 3.0 & 92 & 37.1 & 31.5 & 1 & Micro & $\begin{array}{l}\text { ACE inhibitor; } \\
\text { CCB; placebo }\end{array}$ & $\begin{array}{c}-9.0 ;-4.0 \\
\quad-5.7\end{array}$ & $\begin{array}{c}0 / 32 ; 0 / 26 \\
0 / 34\end{array}$ & - & - \\
\hline FACET 1998 & 3.5 & 380 & 63.1 & 40.5 & 2 & $\begin{array}{l}\text { Normo and } \\
\text { micro }\end{array}$ & $\begin{array}{l}\text { ACE inhibitor; } \\
\text { CCB }\end{array}$ & $-9.71 ;-11.7$ & 4/189; 5/191 & - & - \\
\hline Garg et al 1998 & 1.0 & 11 & 25.4 & 72.7 & 1 & Micro & $\begin{array}{l}\text { ACE inhibitor; } \\
\text { placebo }\end{array}$ & $-7.9 ;-1.6$ & $0 / 7 ; 0 / 4$ & - & - \\
\hline $\begin{array}{l}\text { Nankervis et al } \\
1998\end{array}$ & 3.0 & 40 & 46.0 & 20.0 & Mixed & Micro & $\begin{array}{l}\text { ACE inhibitor; } \\
\text { placebo }\end{array}$ & $-3.0 ; 2.3$ & $0 / 20 ; 3 / 20$ & - & - \\
\hline Ravid et al 1998 & 6.0 & 194 & 55.0 & 61.3 & 2 & Normo & $\begin{array}{l}\text { ACE inhibitor; } \\
\text { placebo }\end{array}$ & $1.8 ; 5.9$ & $3 / 97 ; 2 / 97$ & - & - \\
\hline
\end{tabular}


Table 1 (continued)

\begin{tabular}{|c|c|c|c|c|c|c|c|c|c|c|c|}
\hline \multirow[b]{2}{*}{ Trial } & \multirow[b]{2}{*}{$\begin{array}{l}\text { Follow-up } \\
\text { (years) }\end{array}$} & \multirow[b]{2}{*}{$\begin{array}{c}\text { No of } \\
\text { patients }\end{array}$} & \multirow[b]{2}{*}{$\begin{array}{c}\text { Mean } \\
\text { age } \\
\text { (years) }\end{array}$} & \multirow[b]{2}{*}{$\begin{array}{c}\text { Female } \\
(\%)\end{array}$} & \multirow[b]{2}{*}{$\begin{array}{l}\text { Type of } \\
\text { diabetes }\end{array}$} & \multirow[b]{2}{*}{$\begin{array}{c}\text { Level of } \\
\text { albuminuria* }\end{array}$} & \multirow[b]{2}{*}{ Treatment } & \multirow[b]{2}{*}{$\begin{array}{l}\text { Change in } \\
\text { MAP (mm } \\
\mathrm{Hg})\end{array}$} & \multicolumn{3}{|c|}{ Outcomes } \\
\hline & & & & & & & & & $\begin{array}{l}\text { All cause } \\
\text { mortality }\end{array}$ & $\begin{array}{l}\text { End } \\
\text { stage } \\
\text { renal } \\
\text { disease }\end{array}$ & $\begin{array}{l}\text { Doubling } \\
\text { of serum } \\
\text { creatinine }\end{array}$ \\
\hline $\begin{array}{l}\text { Cordonnier et al } \\
1999\end{array}$ & 2.0 & 22 & 47.0 & 18.2 & 2 & $\begin{array}{l}\text { Micro and } \\
\text { macro }\end{array}$ & $\begin{array}{l}\text { ACE inhibitor; } \\
\text { placebo }\end{array}$ & $-5.0 ;-1.0$ & $0 / 11 ; 0 / 11$ & - & - \\
\hline Fogari et al 1999 & 2.0 & 107 & 56.3 & 0.0 & 2 & Macro & $\begin{array}{l}\text { ACE inhibitor; } \\
\text { CCB }\end{array}$ & $-14.2 ;-12.4$ & - & $1 / 54 ; 1 / 53$ & - \\
\hline $\begin{array}{l}\text { Mathiesen et al } \\
1999\end{array}$ & 4.0 & 44 & 28.9 & 50.0 & 1 & Micro & $\begin{array}{l}\text { ACE inhibitor; } \\
\text { placebo }\end{array}$ & $-5.3 ;-0.7$ & $0 / 21 ; 0 / 23$ & - & - \\
\hline $\begin{array}{l}\text { Muirhead et al } \\
1999 \\
\end{array}$ & 1.1 & 122 & 56.0 & 27.0 & 2 & Micro & $\begin{array}{l}\text { ACE inhibitor; } \\
\text { ARB; placebo }\end{array}$ & $\begin{array}{c}-1.7 ;-2.3 \\
0.03 \\
\end{array}$ & $\begin{array}{c}0 / 29 ; 0 / 62 \\
0 / 31 \\
\end{array}$ & - & - \\
\hline ATLANTIS 2000 & 2.0 & 134 & 40.0 & 29.1 & 1 & Micro & $\begin{array}{l}\text { ACE inhibitor; } \\
\text { placebo }\end{array}$ & $-2.3 ; 3.3$ & $5 / 88 ; 0 / 46$ & - & - \\
\hline $\begin{array}{l}\text { Lacourcière et al } \\
2000\end{array}$ & 1.0 & 103 & 58.5 & 19.4 & 2 & $\begin{array}{l}\text { Micro and } \\
\text { macro }\end{array}$ & $\begin{array}{l}\text { ACE inhibitor; } \\
\text { ARB }\end{array}$ & $-11.3 ;-11.9$ & $0 / 51 ; 0 / 52$ & - & - \\
\hline Tarnow 2000 & 4.0 & 52 & 38.1 & 38.5 & 1 & Macro & $\begin{array}{l}\text { ACE inhibitor; } \\
\text { CCB }\end{array}$ & $-8.0 ;-2.0$ & $0 / 25 ; 3 / 27$ & $2 / 25 ; 3 / 27$ & - \\
\hline Bojestig et al 2001 & 2.0 & 55 & 39.7 & 25.5 & 1 & Micro & $\begin{array}{l}\text { ACE inhibitor; } \\
\text { placebo }\end{array}$ & $2.0 ; 2.7$ & $0 / 37 ; 0 / 18$ & - & - \\
\hline $\begin{array}{l}\text { Deerochanawong } \\
\text { et al } 2001 \\
\end{array}$ & 1.0 & 60 & 56.1 & 70.0 & 2 & Micro & $\begin{array}{l}\text { ACE inhibitor; } \\
\text { CCB }\end{array}$ & $-0.4 ;-2.7$ & $0 / 30 ; 0 / 30$ & - & - \\
\hline ESPRIT 2001 & 3.0 & 54 & 38.0 & 37.0 & 1 & $\begin{array}{l}\text { Micro and } \\
\text { macro }\end{array}$ & $\begin{array}{l}\text { ACE inhibitor; } \\
\text { CCB; placebo }\end{array}$ & $3.7 ; 2.3 ; 3.3$ & $\begin{array}{c}0 / 18 ; 0 / 18 \\
0 / 18\end{array}$ & - & - \\
\hline IDNT 2001 & 2.5 & 1715 & 58.9 & 33.5 & 2 & Macro & $\begin{array}{l}\text { ARB; CCB; } \\
\text { placebo }\end{array}$ & $\begin{array}{c}-13.3 \\
-12.7 ;-9.3\end{array}$ & $\begin{array}{l}87 / 579 \\
83 / 567 \\
93 / 569 \\
\end{array}$ & $\begin{array}{c}82 / 579 \\
104 / 567 \\
101 / 569\end{array}$ & $\begin{array}{c}98 / 579 \\
144 / 567 \\
135 / 569 \\
\end{array}$ \\
\hline IRMA-2 2001 & 2.0 & 590 & 58.0 & 31.5 & 2 & Micro & ARB; placebo & $-8.7 ;-7.7$ & $3 / 389 ; 1 / 201$ & $\begin{array}{l}0 / 389 \\
0 / 201 \\
\end{array}$ & $\begin{array}{l}0 / 389 \\
0 / 201\end{array}$ \\
\hline Jerums 2001 & 2.0 & 42 & 30.8 & 59.5 & 1 & Micro & $\begin{array}{l}\text { ACE inhibitor; } \\
\text { CCB; placebo }\end{array}$ & $\begin{array}{c}-7.7 ;-3.7 \\
2.7 \\
\end{array}$ & $\begin{array}{c}0 / 17 ; 1 / 13 \\
0 / 12 \\
\end{array}$ & - & - \\
\hline Kopf et al 2001 & 1.0 & 46 & 52.1 & 32.6 & Mixed & Micro & $\begin{array}{l}\text { ACE inhibitor; } \\
\text { CCB }\end{array}$ & $-13.5 ;-17.7$ & $0 / 23 ; 0 / 23$ & - & - \\
\hline Kventy et al 2001 & 3.0 & 89 & 45.0 & 43.8 & 1 & Normo & $\begin{array}{l}\text { ACE inhibitor; } \\
\text { placebo }\end{array}$ & $4.0 ; 0$ & $0 / 43 ; 0 / 46$ & - & - \\
\hline RENAAL 2001 & 3.4 & 1513 & 60.0 & 36.8 & 2 & Macro & ARB; placebo & $-9.6 ;-9.2$ & $\begin{array}{l}158 / 751 \\
155 / 762 \\
\end{array}$ & $\begin{array}{l}147 / 751 \\
194 / 762 \\
\end{array}$ & $\begin{array}{l}162 / 751 \\
198 / 762 \\
\end{array}$ \\
\hline Fogari et al 2002 & 4.0 & 309 & 62.5 & 43.4 & 2 & Micro & $\begin{array}{l}\text { ACE } \\
\text { inhibitor+CCB; } \\
\text { ACE inhibitor; } \\
\text { CCB }\end{array}$ & $\begin{array}{c}-21.0 \\
-13.6 ;-15.2\end{array}$ & $\begin{array}{c}2 / 104 ; 3 / 102 \\
4 / 103\end{array}$ & - & - \\
\hline $\begin{array}{l}\text { JAPAN-IDDM } \\
2002 \\
\end{array}$ & 1.5 & 79 & 33.5 & 64.6 & 1 & $\begin{array}{l}\text { Micro and } \\
\text { macro }\end{array}$ & $\begin{array}{l}\text { ACE inhibitor; } \\
\text { placebo }\end{array}$ & $1.3 ; 3.3$ & $0 / 52 ; 0 / 27$ & $0 / 52 ; 0 / 27$ & $2 / 52 ; 2 / 27$ \\
\hline BENEDICT 2004 & 3.0 & 1204 & 62.3 & 47.3 & 2 & Normo & $\begin{array}{l}\text { ACE } \\
\text { inhibitor+CCB; } \\
\text { ACE inhibitor; } \\
\text { CCB; placebo }\end{array}$ & $\begin{array}{l}-8.3 ;-7.6 \\
-6.4 ;-6.1\end{array}$ & $\begin{array}{l}2 / 300 ; 4 / 301 ; \\
2 / 303 ; 5 / 300\end{array}$ & - & - \\
\hline DETAIL 2004 & 5.0 & 250 & 60.6 & 27.2 & 2 & Mixed & $\begin{array}{l}\text { ACE inhibitor; } \\
\text { ARB }\end{array}$ & $-4.1 ;-6.5$ & $6 / 130 ; 6 / 120$ & $\begin{array}{l}0 / 130 \\
0 / 120 \\
\end{array}$ & - \\
\hline $\begin{array}{l}\text { DIABHYCAR } \\
2004 \\
\end{array}$ & 3.0 & 4912 & 65.1 & 30.1 & 2 & $\begin{array}{l}\text { Micro and } \\
\text { macro }\end{array}$ & $\begin{array}{l}\text { ACE inhibitor; } \\
\text { placebo }\end{array}$ & $-2.4 ;-2.0$ & $\begin{array}{l}334 / 2443 \\
324 / 2469\end{array}$ & $\begin{array}{l}11 / 2443 \\
12 / 2469\end{array}$ & $\begin{array}{c}48 / 2443 \\
60 / 2469\end{array}$ \\
\hline NESTOR 2004 & 1.0 & 569 & 59.2 & 35.5 & 2 & Micro & $\begin{array}{l}\text { ACE inhibitor; } \\
\text { diuretic }\end{array}$ & $-15.0 ;-16.6$ & 1/286; 2/283 & - & - \\
\hline Ko et al 2005 & 1.0 & 42 & 61.0 & 59.5 & 2 & Mixed & $\begin{array}{l}\text { ACE inhibitor; } \\
\text { ARB }\end{array}$ & $-3.3 ;-3.0$ & $0 / 20 ; 0 / 22$ & - & - \\
\hline Rizzoni et al 2005 & 1.0 & 15 & 58.0 & 26.7 & 2 & $\begin{array}{l}\text { Normo and } \\
\text { micro }\end{array}$ & $\begin{array}{l}\text { ACE inhibitor; } \\
\text { ARB }\end{array}$ & $-15.5 ;-7.9$ & $0 / 7 ; 0 / 8$ & - & - \\
\hline Schram et al 2005 & 1.0 & 70 & 61.7 & 38.6 & 2 & $\begin{array}{l}\text { Normo and } \\
\text { micro }\end{array}$ & $\begin{array}{l}\text { ACE inhibitor; } \\
\text { ARB; diuretic }\end{array}$ & $\begin{array}{c}-14.3 \\
-14.7 ;-14.0\end{array}$ & $\begin{array}{l}0 / 22 ; 0 / 24 \\
0 / 24\end{array}$ & - & - \\
\hline
\end{tabular}


Table 1 (continued)

\begin{tabular}{|c|c|c|c|c|c|c|c|c|c|c|c|}
\hline \multirow[b]{2}{*}{ Trial } & \multirow[b]{2}{*}{$\begin{array}{c}\begin{array}{c}\text { Follow-up } \\
\text { (years) }\end{array}\end{array}$} & \multirow[b]{2}{*}{$\begin{array}{l}\text { No of } \\
\text { patients }\end{array}$} & \multirow[b]{2}{*}{$\begin{array}{c}\text { Mean } \\
\text { age } \\
\text { (years) }\end{array}$} & \multirow[b]{2}{*}{$\begin{array}{l}\text { Female } \\
(\%)\end{array}$} & \multirow[b]{2}{*}{$\begin{array}{r}\text { Type of } \\
\text { diabetes }\end{array}$} & \multirow[b]{2}{*}{$\begin{array}{l}\text { Level of } \\
\text { albuminuria* }\end{array}$} & \multirow[b]{2}{*}{ Treatment } & \multirow[b]{2}{*}{$\begin{array}{c}\text { Change in } \\
\text { MAP (mm } \\
\mathrm{Hg})\end{array}$} & \multicolumn{3}{|c|}{ Outcomes } \\
\hline & & & & & & & & & $\begin{array}{l}\text { All cause } \\
\text { mortality }\end{array}$ & $\begin{array}{l}\text { End } \\
\text { stage } \\
\text { renal } \\
\text { disease }\end{array}$ & $\begin{array}{l}\text { Doubling } \\
\text { of serum } \\
\text { creatinine }\end{array}$ \\
\hline ABCD-2V 2006 & 1.9 & 129 & 56.1 & 32.6 & 2 & $\begin{array}{l}\text { Normo and } \\
\text { micro }\end{array}$ & ARB; placebo & $-8.7 ;-3.3$ & $1 / 66 ; 0 / 63$ & - & - \\
\hline $\begin{array}{l}\text { Katayama et al } \\
2006\end{array}$ & 1.0 & 87 & 66.5 & 48.3 & 2 & $\begin{array}{l}\text { Normo and } \\
\text { micro }\end{array}$ & $\mathrm{ARB}+\mathrm{CCB} ; \mathrm{ARB}$ & $-2.7 ;-1.3$ & $0 / 46 ; 0 / 41$ & - & - \\
\hline Tong et al 2006 & 2.0 & 38 & 65.8 & 34.2 & 2 & $\begin{array}{l}\text { Micro and } \\
\text { macro }\end{array}$ & $\begin{array}{l}\text { ACE inhibitor; } \\
\text { placebo }\end{array}$ & $-2.7 ;-4.0$ & $0 / 18 ; 0 / 20$ & 0/18;0/20 & $4 / 18 ; 5 / 20$ \\
\hline ADVANCE 2007 & 4.3 & 11140 & - & - & 2 & Mixed & $\begin{array}{l}\text { ACE } \\
\text { inhibitor+diuretic; } \\
\text { placebo }\end{array}$ & $-8.3 ;-7.0$ & $\begin{array}{l}408 / 5569 \\
471 / 5571\end{array}$ & $\begin{array}{l}25 / 5569 \\
21 / 5571\end{array}$ & $\begin{array}{l}55 / 5569 \\
45 / 5571\end{array}$ \\
\hline $\begin{array}{l}\text { DIRECT-Prevent } \\
12008 \\
\end{array}$ & 4.0 & 1421 & 29.7 & 43.3 & 1 & Normo & ARB; placebo & - & $7 / 711 ; 5 / 710$ & - & - \\
\hline $\begin{array}{l}\text { DIRECT-Protect } 1 \\
2008\end{array}$ & 4.0 & 1905 & 33.5 & 42.7 & 1 & Normo & ARB; placebo & - & $7 / 951 ; 8 / 954$ & - & - \\
\hline $\begin{array}{l}\text { DIRECT-Protect } 2 \\
2008\end{array}$ & 4.0 & 1905 & 56.8 & 50.2 & 2 & Normo & ARB; placebo & - & $\begin{array}{l}37 / 951 \\
35 / 954\end{array}$ & - & - \\
\hline GUARD 2008 & 1.0 & 332 & 57.7 & 34.6 & 2 & Mixed & $\begin{array}{l}\text { ACE } \\
\text { inhibitor+CCB; } \\
\text { ACE } \\
\text { inhibitor+diuretic }\end{array}$ & $-15.5 ;-12.9$ & $1 / 166 ; 2 / 166$ & - & - \\
\hline Perrin et al 2008 & 5.0 & 13 & 23.5 & 53.8 & 1 & Normo & ARB; placebo & $-3.7 ; 8.7$ & $0 / 7 ; 0 / 6$ & - & - \\
\hline $\begin{array}{l}\text { Kohlmann et al } \\
2009\end{array}$ & 1.0 & 110 & 62.7 & 43.6 & 2 & Micro & $\begin{array}{l}\text { ACE } \\
\text { inhibitor+CCB; } \\
\text { ARB+diuretic }\end{array}$ & $-17.1 ;-16.0$ & $0 / 54 ; 0 / 56$ & - & - \\
\hline Mehdi et al 2009 & 1.0 & 80 & 51.1 & 52.5 & Mixed & Macro & $\begin{array}{l}\text { ACE inhibitor; } \\
\text { ACE } \\
\text { inhibitor+diuretic; } \\
\text { ACE } \\
\text { inhibitor+ARB }\end{array}$ & $\begin{array}{c}-5.0 ; 1.7 \\
-4.7\end{array}$ & $\begin{array}{c}\text { 0/27; 0/27; } \\
\text { 1/26 }\end{array}$ & - & - \\
\hline MITEC 2009 & 3.0 & 209 & 59.7 & 36.4 & 2 & Mixed & ARB; CCB & $-17.7 ;-19.0$ & 0/100; 0/109 & - & - \\
\hline RASS 2009 & 5.0 & 285 & 29.7 & 53.7 & 1 & Normo & $\begin{array}{l}\text { ACE inhibitor; } \\
\text { ARB; placebo }\end{array}$ & $\begin{array}{c}-5.7 ;-4.3 ; \\
-2.0\end{array}$ & $\begin{array}{c}1 / 94 ; 1 / 96 \\
1 / 95\end{array}$ & $\begin{array}{c}0 / 94 ; \\
0 / 96 ; 0 / 95\end{array}$ & - \\
\hline ROADMAP 2011 & 3.2 & 4447 & 57.7 & 53.9 & 2 & Normo & ARB; placebo & $-8.2 ;-5.0$ & $\begin{array}{l}26 / 2232 \\
15 / 2215 \\
\end{array}$ & $\begin{array}{l}0 / 2232 ; \\
0 / 2215\end{array}$ & $\begin{array}{l}\text { 23/2232; } \\
\text { 23/2215 }\end{array}$ \\
\hline
\end{tabular}

$\mathrm{ABCD}=$ Appropriate Blood Pressure Control in Diabetes; ABCD-2V=The Appropriate Blood Pressure Control in Diabetes Part 2 with Valsartan; ADVANCE=Action in Diabetes and Vascular disease: preterAx and diamicroN-MR Controlled Evaluation; ATLANTIS=Ace-Inhibitor Trial to Lower Albuminuria in Normotensive Insulin-Dependent Subjects; BENEDICT=Bergamo Nephrologic Diabetes Complications Trial; DETAIL=Diabetics Exposed to Telmisartan and Enalapril; DIABHYCAR=Noninsulin-Dependent Diabetes, Hypertension, Microalbuminuria, Proteinuria, Cardiovascular Events, and Ramipril; DIRECT=Dlabetic REtinopathy Candesartan Trials; ESPRIT=European Study for the Prevention of Renal Disease in Type 1 Diabetes; FACET=Fosinopril versus Amlodipine Cardiovascular Events Trial; GUARD=Gauging Albuminuria Reduction With Lotrel in Diabetic Patients With Hypertension; IDNT=Irbesartan Diabetic Nephropathy Trial; IRMA-2=Irbesartan Microalbuminuria II; JAPAN-IDDM=Japanese trial of ACE inhibitors on renal protection against nephropathy in IDDMs; MITEC=Media Intima Thickness Evaluation with Candesartan cilexetil; NESTOR=Natrilix SR versus Enalapril Study in hypertensive Type 2 diabetics with MicrOalbuminuRia; RASS=Renin-Angiotensin System Study; RENAAL=Reduction of Endpoints in NIDDM with the Angiotensin II Antagonist Losartan; ROADMAP=Randomised Olmesartan and Diabetes Microalbuminuria Prevention.

$\mathrm{ACE}=$ angiotensin converting enzyme; $\mathrm{ARB}=$ angiotensin receptor blocker; $\mathrm{CCB}=$ calcium channel blocker; $\mathrm{MAP}=$ mean arterial pressure See panel for full trial names. See supplementary file for references of included trials in meta-analysis. Outcomes are shown as ratio of event number to total patient number.

*Normoalbuminuria is defined as urine albumin excretion rate below $20 \mu \mathrm{g} / \mathrm{min}$, microalbuminuria as urine albumin excretion rate between $20 \mu \mathrm{g} / \mathrm{min}$ and 200 $\mu \mathrm{g} / \mathrm{min}$, and macroalbuminuria as urine albumin excretion rate above $200 \mu \mathrm{g} / \mathrm{min}$. 
Table 2| Results of network meta-analysis for treatments compared with placebo

\begin{tabular}{|c|c|}
\hline Treatment & Odds ratio $(95 \% \mathrm{Crl})$ \\
\hline \multicolumn{2}{|l|}{ All cause mortality: } \\
\hline ACE inhibitor+CCB & 0.51 (0.15 to 1.35$)$ \\
\hline ACE inhibitor+diuretic & 0.86 (0.59 to 1.26$)$ \\
\hline ACE inhibitor & 0.99 (0.73 to 1.26$)$ \\
\hline $\mathrm{CCB}$ & 1.02 (0.74 to 1.46$)$ \\
\hline ARB & 1.08 (0.87 to 1.39 ) \\
\hline Diuretic & $2.19(0.17$ to 55.70$)$ \\
\hline$\beta$ blocker & $7.13(1.37 \text { to } 41.39)^{\star}$ \\
\hline $\mathrm{ARB}+\mathrm{CCB}+$ & $4.42 \times 10^{-14}\left(2.81 \times 10^{-51}\right.$ to $\left.4.25 \times 10^{5}\right)$ \\
\hline $\mathrm{ARB}+$ diuretic $\dagger$ & $7.06 \times 10^{-3}\left(2.07 \times 10^{-27}\right.$ to $\left.4.38 \times 10^{17}\right)$ \\
\hline ACE inhibitor+ARB $\dagger$ & $2.10 \times 10^{15}\left(90.74\right.$ to $\left.7.26 \times 10^{26}\right)$ \\
\hline \multicolumn{2}{|l|}{ End stage renal disease: } \\
\hline ACE inhibitor & 0.71 (0.39 to 1.28$)$ \\
\hline ARB & 0.73 (0.43 to 1.25$)$ \\
\hline$\beta$ blocker & 0.87 (0.10 to 6.34$)$ \\
\hline $\mathrm{CCB}$ & $1.01(0.54$ to 1.90$)$ \\
\hline ACE inhibitor+diuretic & 1.20 (0.50 to 2.93$)$ \\
\hline \multicolumn{2}{|c|}{ Doubling of serum creatinine level: } \\
\hline ACE inhibitor & $0.58(0.32 \text { to } 0.90)^{*}$ \\
\hline ARB & 0.76 (0.47 to 1.32$)$ \\
\hline $\mathrm{CCB}$ & $1.18(0.57$ to 2.54$)$ \\
\hline ACE inhibitor+diuretic & $1.22(0.49$ to 3.03$)$ \\
\hline$\beta$ blocker & $4.87(0.77$ to 34.61$)$ \\
\hline
\end{tabular}

$\mathrm{Crl}=$ credible interval; $\mathrm{ACE}=$ angiotensin converting enzyme; $\mathrm{ARB}=$ angiotensin receptor blocker; $\mathrm{CCB}=$ calcium channel blocker. *Statistically significant difference.

†Extremely wide credible intervals owing to small patient numbers and rare death events among treatment arm. 


\section{Figures}

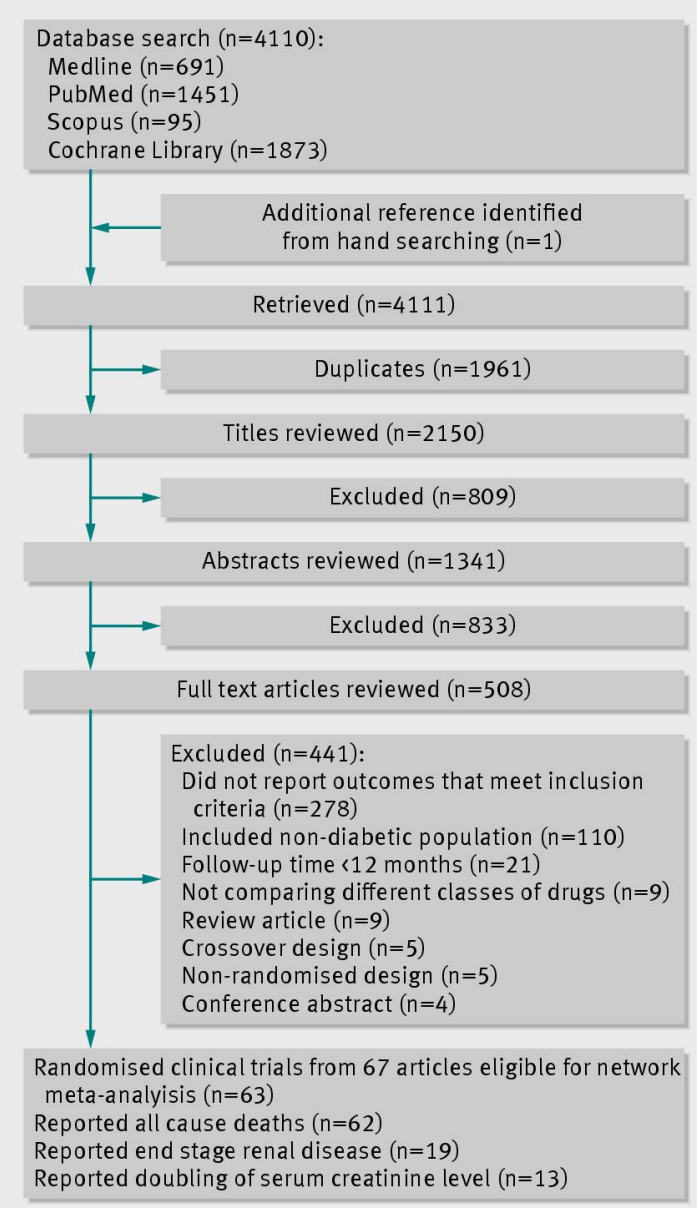

Fig 1 Summary of trial identification and selection 

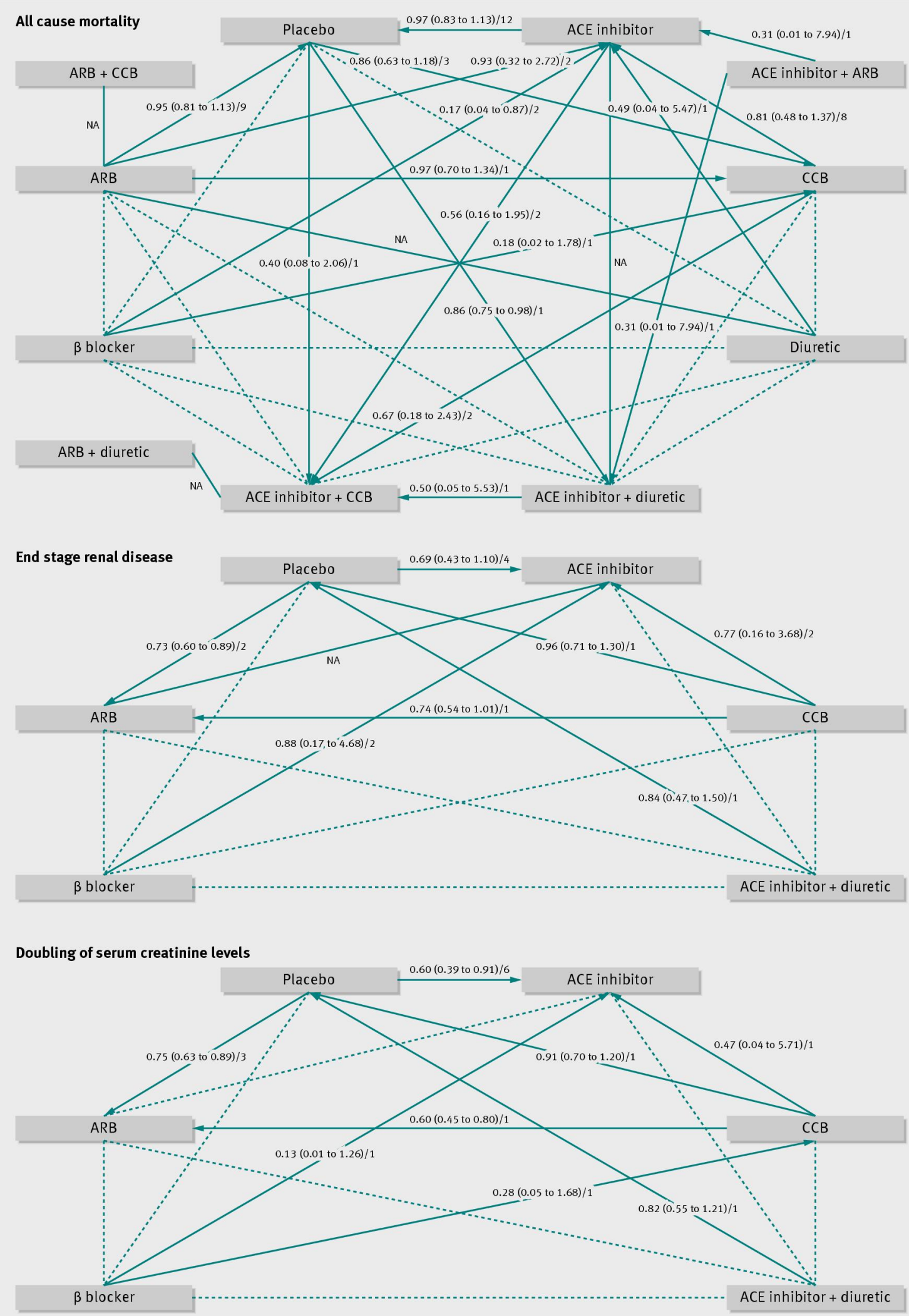

Fig 2 Network of eligible treatment comparisons for outcomes of all cause mortality, end stage renal disease, and doubling of serum creatinine levels. For each pairwise comparison, the arrowhead points to class of antihypertensive treatment with lower risk in traditional random effects meta-analyses. Results of direct comparison are presented as summary odds ratio (95\% confidence interval)/number of trials providing information. The result of a single trial is provided when traditional meta-analysis in a specific comparison is not feasible. Solid lines represent direct comparisons and dotted lines indirect comparisons. $\mathrm{ACE}=$ angiotensin converting enzyme; $\mathrm{ARB}=$ angiotensin receptor blocker; $\mathrm{CCB}=\mathrm{calcium}$ channel blocker; $\mathrm{NA}=$ not applicable in direct comparison owing to zero events in both treatment arms 
All cause mortality
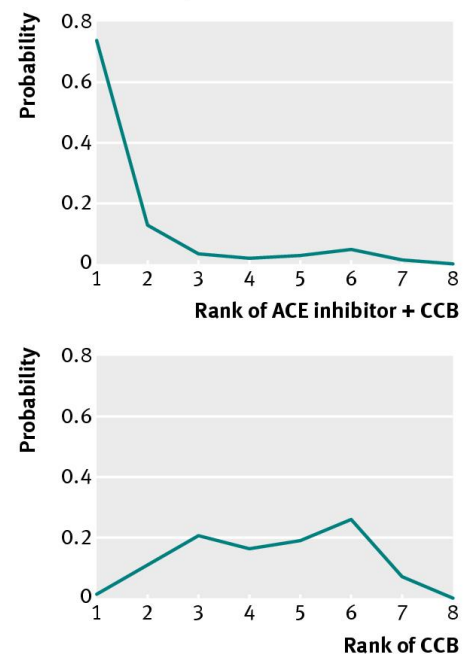

End stage renal disease
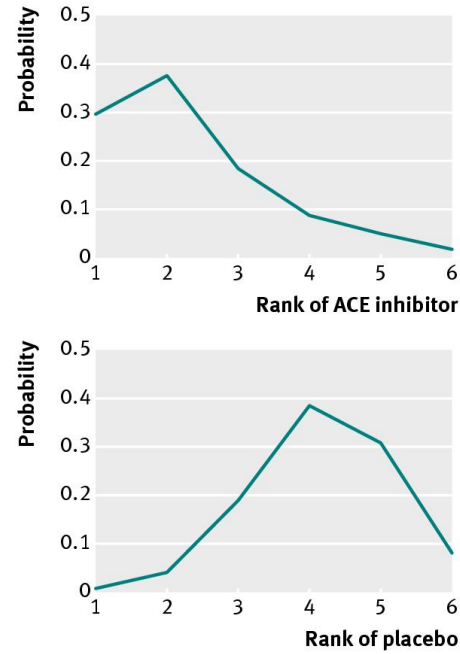

Doubling of serum creatinine levels
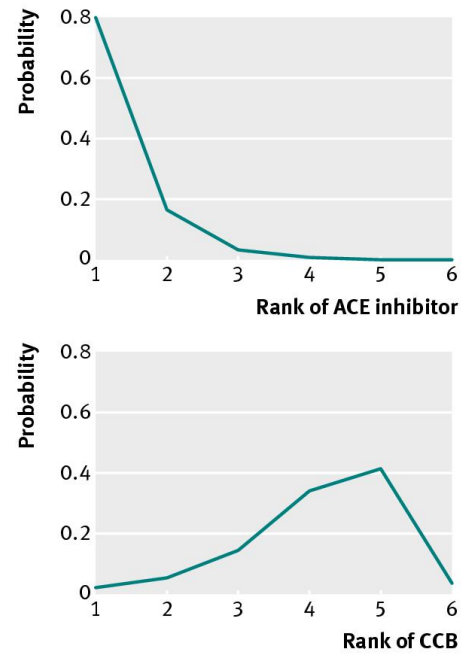
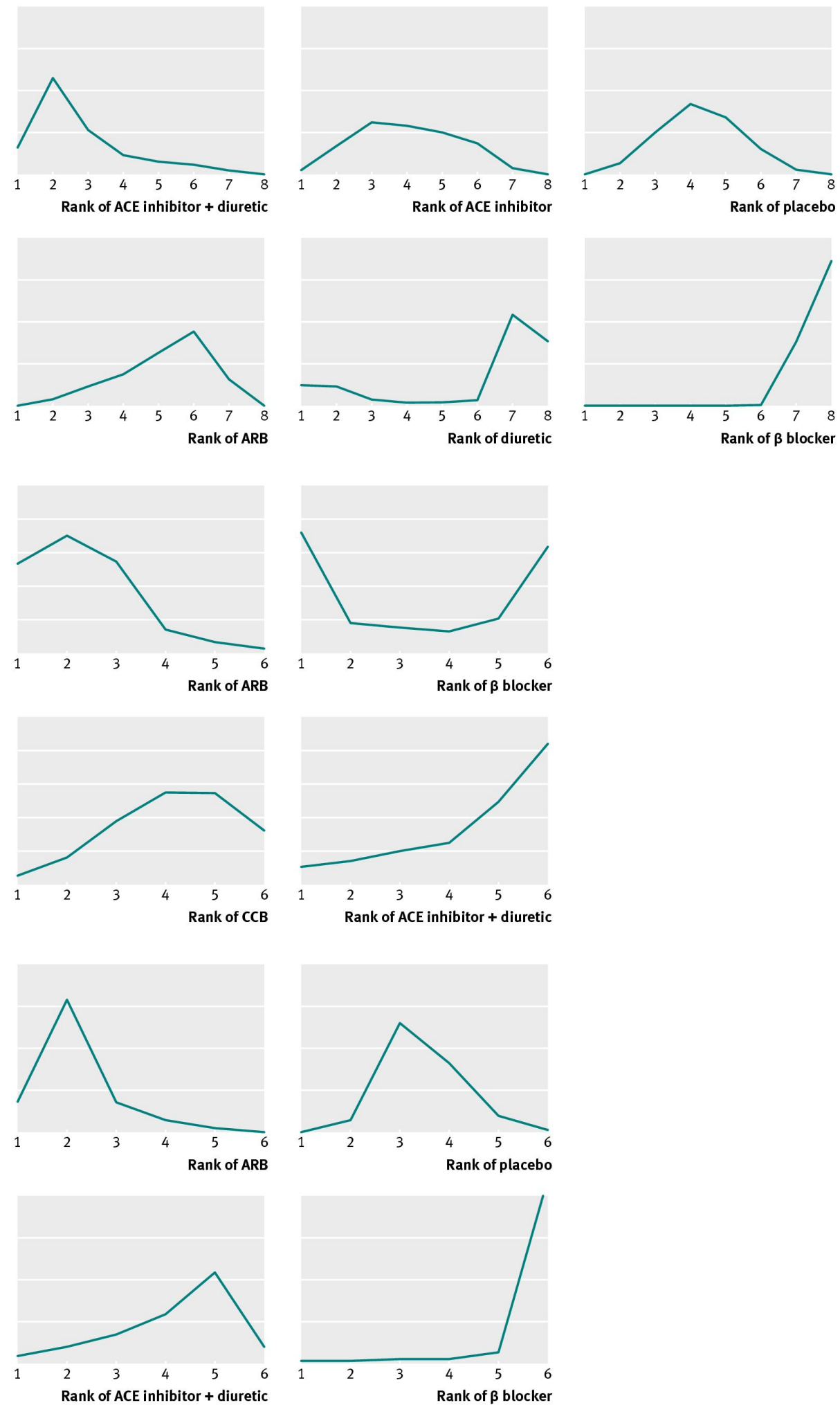

Fig 3 Ranking of treatment strategies based on probability of their protective effects on outcomes of all cause mortality, end stage renal disease, and doubling of serum creatinine levels. Angiotensin receptor blocker (ARB) plus calcium channel blocker (CCB); ARB plus diuretic, and angiotensin converting enzyme (ACE) inhibitor plus ARB were not ranked owing to wide credible intervals 
Treatment comparisons

ACE inhibitor + CCB $v \beta$ blocker $\mathrm{ACE}$ inhibitor + CCB $v$ placebo ACE inhibitor + CCB $v$ placebo $\mathrm{ACE}$ inhibitor + CCB $v$ diuretic $A C E$ inhibitor + $C C B \vee C C B$ $A C E$ inhibitor + CCB $v C C B$ ACE inhibitor + CCB $v$ ACE inhibitor $A C E$ inhibitor + CCB $\vee A C E$ inhibitor ACE inhibitor + CCB $v$ ARB

$A C E$ inhibitor + CCB $v$ ACE inhibitor+diuretic $A C E$ inhibitor + $C C B \vee A C E$ inhibitor+diuretic ACE inhibitor + diuretic $v \beta$ blocker ACE inhibitor + diuretic $v$ placebo ACE inhibitor + diuretic $v$ placebo ACE inhibitor + diuretic $v$ diuretic ACE inhibitor + diuretic $v$ CCB ACE inhibitor + diuretic $v$ ACE inhibitor ACE inhibitor + diuretic $v$ ARB ARB $v \beta$ blocker $A R B v$ placebo ARB $v$ placebo ARB $v$ diuretic ARB $v$ CCB ARB $v$ CCB $A R B v A C E$ in hibitor ARB $v$ ACE inhibitor ACE inhibitor $v \beta$ blocker ACE inhibitor $v \beta$ blocker ACE inhibitor $v$ placebo ACE inhibitor $v$ placebo ACE inhibitor $v$ diuretic ACE inhibitor $v$ diuretic ACE inhibitor $v$ CCB ACE inhibitor $v C C B$ CCB $v \beta$ blocker CCB $v \beta$ blocker $C C B v$ placebo CCB $v$ placebo CCB $v$ diuretic Diuretic $v \beta$ blocker Diuretic $v$ placebo Placebo $v \beta$ blocker

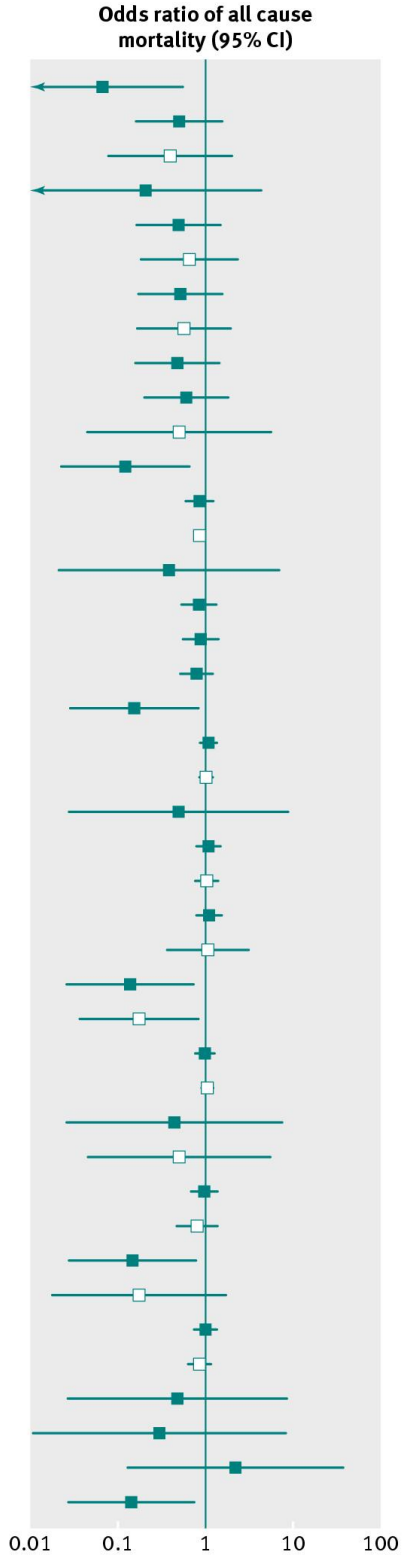

Fig 4 Forest plot for results from bayesian network meta-analysis (solid squares) and those from traditional pairwise meta-analysis (blank squares) for outcomes of all cause mortality, end stage renal disease, and doubling of serum creatinine levels. Squares represent pooled estimates of odds ratio. Lines for $95 \%$ confidence intervals represent $95 \%$ credible intervals in bayesian network meta-analysis and $95 \%$ confidence intervals in traditional pairwise meta-analysis. The result of a single trial is provided as direct evidence when traditional meta-analysis in a specific comparison is not feasible. Angiotensin receptor blocker (ARB) plus calcium channel blocker (CCB), ARB plus diuretic, and angiotensin converting enzyme (ACE) inhibitor plus $A R B$ were not plotted owing to unstable estimated effects and extremely wide credible intervals 